\title{
Understanding of Beach Abrasion Concepts in Elementary School Students
}

\author{
$1^{\text {st }}$ Yonarlianto Tembang* \\ Departmen of Pre-School and \\ Elementary School Education \\ Universitas Musuamus \\ Merauke, Indonesia \\ yonartembang@unmus.ac.id
}

\author{
$2^{\text {st }}$ Ratna Purwanty \\ Departmen of Pre-School and \\ Elementary School Education \\ Universitas Musuamus \\ Merauke, Indonesia \\ ratnapurwanty@unmus.ac.id
}

\author{
$3^{\text {st }}$ Andreas Au Hurit \\ Departmen of Pre-School and \\ Elementary School Education \\ Universitas Musuamus \\ Merauke, Indonesia \\ andreashurit@unmus.ac.id
}

\begin{abstract}
This study aims to describe the understanding of the concept of beach abrasion material in elementary school students at SDN 2 Merauke. This research is a qualitative descriptive study conducted on grade IV elementary school students with 32 respondents. Data collection methods used are observation, interviews, and diagnostic tests. The research was conducted in October 2018 according to the schedule of school lecturers to make it easier to collect data obtained from supporting sources of this study. The data is then analysed descriptively through four stages: data collection, data reduction, data presentation and drawing conclusions. The results of this study indicate that students' understanding of the concept of beach abrasion material in elementary schools varies greatly. This shows that the ability of students to understand material about coastal abrasion of concepts that have been learned by students during the learning process. The average understanding of scientific concepts obtained by students is $\mathbf{2 4 . 6 \%}$ while $\mathbf{5 5 . 0 \%}$ are misconceptions and those who do not answer or repeat questions as reasons for answers are $20.4 \%$. The dominant concepts that experience misconception are; (1) understanding the concept of changes in the appearance of the earth on land $(60 \%)$, (2) understanding the concept of the types of changes caused by the appearance of the earth $(50 \%)$, (3) understanding the concept of coastal abrasion caused by sea waves $(57 \%)$ (4) Understand the concept of erosion on high land $(65 \%)$, (5) understand the concept of how to prevent landslides on high land $(50 \%)$.
\end{abstract}

Keywords: concept understanding, beach abrasion, misconception

\section{INTRODUCTION}

The challenge of the 21 st century world society requires that humans excel in science. Education in the 21 st century is no longer focused on memorizing core subject matter, therapeutics also gives emphasis to the life skills of life skills, learning and thinking skills of learning and thinking skills, literacy in information and communication technology (ICT literacy) [1]. In order to improve students' learning abilities in the classroom the teacher is guided to be able to develop the process of learning activities by using more each lesson process with student involvement so that the specified learning objectives can be achieved well [2]. Observations in schools and sharing with several teachers in the school and even interviews with prospective teachers who have carried out practices in the field show a tendency for teachers to teach their students with strategies / methods that are less representative and do not support learning itself. Submission of information that is very dominant that points in one direction from the teacher and the lack of opportunity and space for students to interact with objects and problems and develop thinking skills make students unable to develop the abilities they can at the time [3].

Not to mention the guidance of science learning in each theme that forces that learning can be developed in skills and think highly, worksheets that must be in accordance with the objectives that can function to optimize the problems that will later be given an impact on the students after receiving the material that they have learned. Before science is implemented into formal education in a subject, students are already familiar with the basic concepts of science based on a natural phenomenon that is naturally experienced in everyday life in society so that students should have a good understanding of the concepts of science learning. Conceptual understanding or understanding of the concept of science is one indicator that is very important to achieve the success of learning science [4]. In addition, concepts can be interpreted as ideas with the aim of making it easier for students to communicate and allow students to think according to events and facts and identify each concept. There is a relationship between understanding concepts in science learning in the form of mastery of concepts that are in accordance with the agreement of scientists, do not deviate, and do not cause other hypotheses that can cause cognitive conflict with students.

The initial concept is referred to as conception, if students have an initial concept that is not in accordance with scientific concepts, this is called misconception. In fact, one of the problems that is often found in science learning in elementary schools is that there are still many students who experience misconceptions about what they are learning. Based on research conducted by [5] with the acquisition of data in class IV students 15 students and class III as many as 14 students regarding misconceptions that occur in material properties and changes in the form of objects in grades IV and III at SDN 47 Sekadau Pontianak shows that students regarding material properties the properties of liquid objects and for example grade IV students by $80 \%$ misconceptions and in class III students by $78.57 \%$, the concept of the properties of gas objects and for example grade IV students by $73.33 \%$ while in class III by $71.43 \%$, the concept of changes that occur in objects due to heating is only 
implemented in class III and students who experience misconceptions as much as 57.14\% and the concept of changes in the form of objects and examples carried out in class IV students as much as $73.33 \%$, this shows the level of misconception experienced by students in understanding a material that has a very low impact on student learning outcomes. As for some previous studies that also equally examine students' misconceptions show results not much different.

Primary school children tend to be interested in small problems, both artificial problems and problems that directly exist in the surrounding environment. [6] These problems equip children to practice critical and objective thinking skills in solving problems they face. Therefore, science lessons in elementary schools are interesting such as simple inquiry, discussion and direct observation of what they are doing and what they are doing in an experiment. Achievement of students' understanding of concepts can be done with a variety of activities that support the learning process. One of them is by applying a learning model and learning media that can find a conflict to improve the students' negative. Based on observations made in this study during the learning process takes place the teacher does not pay attention to the understanding of concepts achieved by students. The teacher also ignores students who do not understand the concepts he is learning relating to natural science subjects.

Seeing the facts and conditions that occur, it is necessary to have an initial effort to be able to explore the understanding of the concept on the beach abrasion material for elementary school students in class 2 Merauke class IV. For this reason, a study was made at SDN 2 Merauke to find out the concept understanding profile in natural science abrasion subjects to be used as a provision to prevent the occurrence of coastal abrasion on the coast of the city of Merauke and be well preserved. Based on the background of the problem raised in this study is how to understand the concept of beach abrasion in natural science subjects of class IV SDN 2 Merauke, and to know the extent of misconceptions that students get during the learning process. The purpose of this research is to identify and describe the understanding of the conception of coastal abrasion and to find out the extent of students' misconceptions during the learning process.

\section{RESEARCH METHODS}

This research is a qualitative descriptive study. This study is included in the type of qualitative descriptive study because it describes scientifically about the conception patterns in SDN 2 Merauke students, especially in class IV in natural abrasion science subjects. The research design used in qualitative research can be realized with qualitative research stages. Qualitative stages have different main characteristics with quantitative research, where the researcher acts as a research tool. This research was conducted through three stages, namely (1) Pre field stage; this stage is a stage of planning, planning, and preparation of all forms of material needed as material to support the implementation later when in the field; (2) the field stage; At this stage the data collection process is carried out, the researcher uses research tools that have been prepared in the first stage. The tool used in this study is a guide to field notes.
[7] Field notes are used to write down the activities of the teacher during the process of learning through observation, provision of diagnostic tests, and interviews. After that the data is classified as; understanding data concepts, misconceptions and causes / sources of misconceptions experienced by students in their learning. (3) the post-field stage undertaken to analyse the follow-up data that has been taken and then provide the final conclusions, as well as confirmation in the preparation of the report [8].

\section{RESULTS AND DICUSSIONS}

The results of the study of understanding the concept of beach abrasion material SDN 2 Merauke grade IV students there are 3 forms of activities that will be discussed related to understanding the concepts found by students during the learning process takes place in the classroom, based on observations made for three days at school in accordance with existing material that is; (1) The concept of coastal abrasion caused by waves of sea water; (2) The concept of abrasion / erosion caused by sea water; (3) The concept of the impact of aberration / erosion and its prevention on the surrounding environment, while to find out the misconceptions obtained through diagnostic tests can be seen.

\section{A. The Concept Of Beach Abrasion Occurs Due To Waves Of Sea Water}

The data obtained at this stage are observational data, interviews and diagnostic tests on students of SDN 2 Merauke based on students' experience while attending beach abrasion material. A sample of 32 students stated their statements in accordance with the questions given. Students answer according to what they can during the learning process takes place. Researchers conducted interviews with students by asking about what causes beach abrasion. Students are still very difficult to answer some students who were asked could not answer questions, there were 7 students who answered according to questions and there were 17 people answered that did not match the questions given the rest can only be silent and not answer the questions given. The questions posed are the opening questions that are conveyed by the teacher before entering into the subject matter. Students are very difficult to find a concept about the material obtained during the learning process.

Many students who answered not according to this question or misconception made learning when it was not going well. This misconception can occur because (1) there is no support in learning so the learning process is only memorized, a printed book is the only source of learning in the classroom, so that when students are given a question they can only remember what is in the printed book which they read . Learning like this will not last long when students can only be told to memorize the learning that they learn. (2) The learning model used by the teacher during the learning process does not support the learning process activities in accordance with the nature of natural science learning. Methods, approaches, models and techniques that are very instrumental in learning science, because science is open only memorization, but the most important is how students learn by finding concepts that they learn in accordance with everyday life. 


\section{B. The Concept Of Abrasion/Erosion Caused By Wind}

The concept of abrasion / erosion caused by rainwater is the second material on the changes in the appearance of natural features. This material is very closely related to the first lesson, where the first lesson has discussed the causes of coastal abrasion due to sea waves. The question given in this material is how the abrasion / erosion process occurs in accordance with the material learned by students, the questions compiled are questions about the material learned by students during the learning process. Based on the question, it was found that students who answered according to the concept were 8 people in accordance with the questions and 15 students answered the misconceptions or did not match the questions given while 9 students did not answer the questions.

The eight students answered that it was in accordance with the concept of science learning where the answer is abrasion / erosion can occur due to continuous rain down the area so that the strength of the old soil will be lowered by rain water, the reason was given by saying it could be prevented by giving a support or a plant that is planted in the area so that the land which is exposed to rainwater is not easily under the rain water so that it can slow down the soil can be reduced. From this answer, it has been shown that 8 students have understood the concept of science learning by describing an answer without seeing an event or experiment carried out. Science learning cannot be separated from learning actions that can involve students during the learning process, teachers can only guide students during the process so that meaningful learning can be obtained by students by actively finding the material he is learning.

Answering questions that do not match the questions there are 15 students who are still far from the concept of learning science. The answer given is that because there are many people who grow trees carelessly, there are also those who answered that it is already common in my area and that is because of the burning of the forest, the questions and answers given are not appropriate and there is no scientific concept in the answer them. The reason is not there, this data is strengthened when observing in class only a few students can answer the questions given by the teacher, many students answer but not according to the question given or misconception. Students who did not answer or repeat the questions as the reason for the answers there were 9 students, this was obtained when conducting interviews with students many students who were silent when asked questions and could not answer these questions, and there were some students who only repeated questions as answers given. Lack of understanding of abrasion / erosion obtained by students shows that students are not fully prepared to participate in the learning day and the readiness of teachers in providing learning is still lacking to support the learning process, this statement is supported from the results of interviews conducted with teachers by asking activities such as anything you do to improve students' understanding of concepts in science learning, have you ever done learning outside the classroom? the teacher's answer is that for activities outside the classroom, it has been carried out with ecosystem material, but the obstacle is that the process of the activity takes quite a long time, whereas the time or Very limited learning hours. When using a learning model or method the teacher says that he has never implemented it.
The teacher should be able to use a teaching aid or learning model that can support learning when delivering material when the teacher is giving a lecture and giving an assignment to students which is only abstract in front of the student without seeing an event that occurs. The experimental method is a solution for science learning that must be applied by teachers in the classroom. This method is very suitable because this learning involves students to find concepts that they learn by doing an action in the classroom by working together, concepts that they build based on what they then do their imagination then they try and the last is to implement or share with other groups. Seeing from the material that there is a very good experimental method used by the teacher.

\section{The Concept Of The Impact Of Abrasion/Erosion And Prevention On The Surrounding Environment}

The third material is the concept of its impact and prevention on the surrounding environment, this needs to be mastered by students because it is very influential on the daily lives of students, most students in SDN 2 Merauke reside in coastal areas in Merauke, this it is very necessary to be understood by students because of its impact later to be able to preserve the environment in their place of residence. The first question given is in your opinion the impact of abrasion / erosion on the surrounding environment do you think students respond to the fact that the Tanis in the area are reduced so that the land can be reduced and some students answer can cause flooding in the area and result in other regional transportation roads can be interrupted due to earth scraping. The answers given by students are in accordance with the concept of science there are 7 students who answer according to the concept while 20 students answer not according to questions or misconceptions, the answers submitted are the occurrence of illegal development in the coast, the absence of plants on the coast so that abrasion can occur and the lack of awareness of the surrounding community about protecting the surrounding environment. The question raised by students is a question of how to prevent it from abrasion / erosion.

Students who did not answer the question there were 6 students this might be because during the learning process students did not pay attention to the material explained by the teacher. Students' understanding of the impact caused by abrasion / erosion is still lacking. Students should understand it more to be able to implement it in their daily lives so they know how the impact of coastal abrasion / erosion. The teacher should have an impact giving an experiment when teaching material about impact and its prevention in beach abrasion / erosion to be understood by students so that it can implement it and see firsthand the impact caused by beach abrasion / erosion. This learning process error can be used as a benchmark for the impact of reviewing lessons that have been done so that in the future science lessons are taught not only by reading or looking at printed books and working on the problems contained in the book but teachers can also use the method by conducting experiments.

The second question given is how do you prevent abrasion / erosion in your environment, 10 students answered in accordance with the scientific concept of science lessons with the answer to the question of preserving plants on the coast, for example planting mangrove trees students give examples and tell situations that they have seen and done in 
their homes, many mangroves in my neighborhood, me and the surrounding community always conserve these trees to prevent coastal abrasion and reduce sea waves to land. The students answered by making large concrete to ward off sea water waves to the mainland so that the coming sea water did making a large concrete in order to prevent abrasion / erosion on the coast and preserve mangrove plants to prevent abrasion / erosion in the vicinity of the Merauke district [9] said that the people of Merauke strongly support the government program year after year by planting mangrove trees in the area around, he also said mangrove tree planting is an annual program carried out by the government in collaboration with the Ministry of PUPR with the aim of controlling water damage that can cause abrasion which is very large in Merauke district. That is the effort made by the local government to prevent abrasion / coastal erosion.

There were 19 students who did not match the questions and were categorized as misconceptions. The answers given by students are memorized in the form of answers but not in accordance with the contents of the questions given. The concept of memorization in elementary school students in science lessons is not effective because they can only answer in accordance with the contents of the book without making students to think in accordance with what they have seen in everyday life. Actually this question is often encountered by students when they are in their environment, but because of the guidance of the teacher who provides learning resources only by using books, students are very difficult to develop their cognitive in finding concepts that they learn. Students who do not answer questions or repeat questions there are 3 students, students are very difficult to describe the words that not bring a question that was inland. Students answer this because they often see it when they are at their place of residence. The government itself has sought to prevent abrasion / erosion on the coast in the district of Merauke by

they learn so that what they learn as if not fully obtained by students. Based on the results of this study regarding the concept of beach abrasion in elementary school students through diagnostic tests understanding the concept of beach abrasion materials for SDN 2

Merauke students varies greatly. Where the percentage of students who do not understand the concept of science (not answering or not misconceptions) is $23.5 \%$. While the percentage of misconceptions is $47.7 \%$ and understanding which is a scientific conception is only $28.8 \%$. This means that most of SDN 2 Merauke students do not yet know about the abrasion concept and still misunderstand the concept of beach abrasion. Dominant concepts dominating this misconception have a percentage above $50 \%$. These concepts include; (1) Understand the concept of changing the appearance of the earth at the border and the sea $60 \%$; (2) Understand the concept of type-change that affects the appearance of the earth 50\%; (3) Understand the concept of $57 \%$ coastal displacement of sea waves; (4) Understand the concept of change at 65\%; (5) Understand the concept of how to replace landslides on high land $50 \%$. While understanding concepts that do not improve misconceptions, namely; (1) Understand the concept of how to prevent coastal abrasion and (2) Understand the concept of preserving the environment on the beach $55 \%$. Can be seen in table 1.

TABLE I. TEST RESUlTS OF SDN 2 MERAUKE STUDENTS' DIAGNOSTIC TESTS ON COASTAL ABRASION MATERIAL

\begin{tabular}{|c|c|c|c|c|}
\hline \multirow{2}{*}{$\begin{array}{c}\text { No } \\
\text { Problem }\end{array}$} & \multirow[b]{2}{*}{ Diagnostic test concept } & \multicolumn{3}{|c|}{ Student answer $(\%)$} \\
\hline & & $\begin{array}{c}\text { Scientific } \\
\text { Concept }\end{array}$ & Misconception & Not a Misconception \\
\hline 1 & $\begin{array}{l}\text { Understand the concept of changing the appearance of the } \\
\text { earth on land and sea }\end{array}$ & 14 & 60 & 26 \\
\hline 2 & $\begin{array}{l}\text { Understand the concept of the types of changes caused by the } \\
\text { appearance of the earth. }\end{array}$ & 18 & 50 & 32 \\
\hline 3 & Understand the concept of sea waves & 17 & 38 & 45 \\
\hline 4 & $\begin{array}{l}\text { Understand the concept of coastal abrasion caused by sea } \\
\text { waves }\end{array}$ & 35 & 57 & 8 \\
\hline 5 & Understand the concept of erosion on high altitude & 9 & 65 & 26 \\
\hline 6 & $\begin{array}{l}\text { Understand the concept of abrasion / erosion caused by rain } \\
\text { water }\end{array}$ & 22 & 45 & 33 \\
\hline 7 & $\begin{array}{l}\text { Understand the concept of how to prevent landslides on high } \\
\text { ground }\end{array}$ & 25 & 50 & 25 \\
\hline 8 & Understand the concept of how to prevent coastal abrasion & 50 & 35 & 15 \\
\hline 9 & $\begin{array}{l}\text { Understand the concept of impacts arising from coastal } \\
\text { abrasion }\end{array}$ & 43 & 38 & 19 \\
\hline 10 & $\begin{array}{l}\text { Understand the concept of preserving the environment on the } \\
\text { beach }\end{array}$ & 55 & 39 & 6 \\
\hline & Average percentage $(\%)$ & 28,8 & 47,7 & 23,5 \\
\hline
\end{tabular}

Based on the results of this study the understanding of the concept of beach abrasion material on students of SDN 2 Merauke obtained several obstacles faced by students during the learning process, namely the first lack of understanding of the concepts given by the teacher to students on natural appearance change material so that based on diagnostic tests provided with 10 questions students scored 28.8\%. [10] that the first challenge of learning science in schools is to provide access to students to construct their own science concepts, and to introduce concepts that have been mutually agreed upon by the community in the surrounding environment.
[11] The role of the teacher is very important in the process of building student knowledge, consequently the learning of science is not just a process of transfer through a single print media or from teacher to student, but the learning process is strived meaningful so that the science content is well understood and can be applied by students [12].

Differences in experiences experienced by students allow students to have a wrong understanding of a concept. It is a misunderstanding of the concept that is called misconception. The results of this study indicate that most 
students are focused on a printed book provided by the teacher so that when students are given questions to answer students recall what they can on the printed book so that mastery of student concepts is very absent. This shows that the material changes in natural appearance students experience obstacles in finding concepts.

The second problem experienced by students in this material is the lack of student participation in learning. According to [13] science is a part of our lives and our lives are part of science, it is emphasized that there are four competencies possessed by students in the 21 st century, namely conceptual understanding, critical thinking, creative thinking, and collaboration and communication [3]. In line with this opinion, the challenges of learning in the $21 \mathrm{st}$ century focus on the process of constructing knowledge. In this case learning is the process of discovery, concepts are built through assimilation and accommodation. In addition to the lack of student participation in learning mistakes understand the concepts that become problems in this study or misconceptions

Based on diagnostic test data, it can be seen that from all the values obtained the value of misconceptions has increased or is very high with a percentage of $55.0 \%$. Factors causing misconceptions not only occur in students but also occur in teachers. This statement is in accordance with the research conducted by [14], of 20 grade 5 elementary school teachers who were randomly selected in the Tasikmadu subdistrict of Karanganyar Regency, it was evident that the teacher experienced misconceptions on science material on the subject of Gaya and Chaya materials and several other studies. In addition to understanding teachers who are not correct or still do not understand the material being taught, another factor is that there are still many teachers who carry out learning only by lectures, teachers rarely carry out demonstration or experimental activities. And besides that, teachers rarely give examples of the application of concepts in everyday life. This causes the students' misconceptions to increase because students are not actively involved either physically or mentally in the learning process.

Apart from students and teachers concept errors also often occur in books that are used as a source of student learning [3]. If the book is used by teachers and students as a source of learning, the teacher and students will experience conception and even further strengthen the misconceptions that have previously occurred [15]. Based on the research results of the research, the input from teachers and students is related to various factors causing misconceptions and not misconceptions that are found in students, so the teacher should make improvements so that misconceptions found in students are not sustainable. The improvements made must be based on the results of identification of the causes of students' own misconceptions.

\section{CONCLUSION}

Based on the findings of this study, this study may be used as a reference for teachers in teaching science subjects especially in order to pay attention to the needs of students in the learning process so that the desired goals and learning outcomes can be achieved properly. And suggestions or recommendations can be made to the teacher so that it is necessary to conduct a misconception study of textbooks containing primary school science materials used by students in primary schools. This needs to be done because through this research found misconceptions originating from textbooks used in primary schools such as textbooks and student books. Second is the learning model used by the teacher during the learning process, the teacher may see and review the learning process so far because it only leads to the teacher, not the students, so by looking back and discouraging learning and increasing understanding of concepts about natural science subjects, and finally is teaching aids or media used in science learning because seeing the learning process so far the teacher is still very easy to use media when teaching science.

\section{ACKNOWLEDGMENT}

Thank you to the Chancellor of Musamus University for facilitating and supporting this publication as well as SDN 2 Merauke who have given permission to conduct research and all of the IJCST Teams in Musamus and processors who are willing to accept this article.

\section{REFERENCES}

[1] H. Peşman and A. Eryilmaz, "Development of a three-tier test to assess misconceptions about simple electric circuits," J. Educ. Res., vol. 103, no. 3, pp. 208-222, 2010.

[2] M. Palobo and Y. Tembang, "Difficulty of Teacher in Implemeting Thematic Learning in Basic Schools in Merauke Papua," Int. J. Res., vol. 7, no. 11, p. 85, 2019.

[3] Z. D. Kirbulut and O. Geban, "Using three-tier diagnostic test to assess students' misconceptions of states of matter," Eurasia J. Math. Sci. Technol. Educ., vol. 10, no. 5, pp. 509-521, 2014.

[4] C. M. H Laeli, "Misconception of Science Learning in Primary School Students," vol. 397, no. Icliqe 2019, pp. 657-671, 2020.

[5] I. K. Sadiqin, U. T. Santoso, and A. Sholahuddin, "Pemahaman konsep IPA siswa SMP melalui pembelajaran problem solving pada topik perubahan benda-benda di sekitar kita," J. Inov. Pendidik. IPA, vol. 3, no. 1, p. 52, 2017.

[6] N. P. Widiawati, K. Pudjawan, and I. G. Margunayasa, "Analisis Pemahaman Konsep Dalam Pembelajaran IPA Pada Siswa Kelas IV SD Di Gugus II Kecamatan Banjar," e-Journal PGSD Univ. Pendidik. Ganesha, vol. 3, no. 1, pp. 12-14, 2015.

[7] Y. Tembang, "Penerapan Model Pembelajaran Think Pair Share Untuk Meningkatkan Aktivitas Belajar Ipa Siswa Kelas IV SD YPPK St. Theresia Buti Merauke," J. Ilm. Sekol. Dasar, vol. 2, no. 1, pp. 46-51, Apr. 2018.

[8] Moleong, Metode Penelitian Kualitarif Edisi Revisi. Bandung: PT Remaja Rosda Karya, 2005.

[9] Ndiken, "Daerah - Abrasi Pantai di Merauke sudah Mengkhawatirkan | KBRN LPP RRI | Portal Berita Radio Nasional dan Internasional,” 2019. [Online]. Available: http://rri.co.id/post/berita/447257/daerah/abrasi_pantai_di_merau ke_sudah_mengkhawatirkan.html. [Accessed: 23-Jul-2019].

[10] E. S. A W Wisudawati, Metodologi Pembelajaran IPA. Jakarta: Bumi Aksara, 2014.

[11] Y. Tembang, M. Palobo, A. K. Hermansyah, and L. A. Prihandoko, "Improving science learning outcomes in material changes in natural appearance," IOP Conf. Ser. Earth Environ. Sci., vol. 343, no. 1, 2019.

[12] E. Galvin and G. Mooney Simmie, "Identification of Misconceptions in the Teaching of Biology: A Pedagogical Cycle of Recognition, Reduction and Removal," High. Educ. Soc. Sci., vol. 8, no. 2, pp. 1-8, 2015.

[13] Y. Yuliati, "Miskonsepsi Siswa pada Pembelajaran IPA serta Remediasinya," J. Chem. Inf. Model., vol. 2, no. 2, pp. 50-58, 2017.

[14] Pujayanto, "Miskonsepsi ipa (fisika) pada guru sd," J. Mater. dan Pembelajaran Fis., vol. 1, no. 1, pp. 22-24, 2012.

[15] M. Palobo and Y. Tembang, "Analisis Kualitas Rancangan Penelitian Tindakan Kelas Guru," MAGISTRA J. Kegur. dan Ilmu Pendidik., vol. 6, no. 2, pp. 119-128, 2019. 